\title{
Possession work on hosted digital consumption objects as consumer ensnarement
}

Article

Accepted Version

Molesworth, M., Watkins, R. and Denegri-Knott, J. (2018) Possession work on hosted digital consumption objects as consumer ensnarement. Journal of the Association for Consumer Research, 1 (2). pp. 246-261. ISSN 2378-1823 doi: https://doi.org/10.1086/685474 Available at https://centaur.reading.ac.uk/79215/

It is advisable to refer to the publisher's version if you intend to cite from the work. See Guidance on citing.

To link to this article DOI: http://dx.doi.org/10.1086/685474

Publisher: University of Chicago Press

All outputs in CentAUR are protected by Intellectual Property Rights law, including copyright law. Copyright and IPR is retained by the creators or other copyright holders. Terms and conditions for use of this material are defined in the End User Agreement.

www.reading.ac.uk/centaur 
Central Archive at the University of Reading

Reading's research outputs online 


\title{
Possession Work on Digital Consumption Objects and Consumer Ensnarement
}

\author{
Mike Molesworth, University of Southampton \\ Rebecca Watkins, Cardiff University \\ Janice Denegri-Knott, Bournemouth University
}

\begin{abstract}
This paper extends prior critical discussions of digital prosumption by demonstrating that prosumer reliant online business models represent new ways to valorise consumer labour through the creation of multiple realities whereby digital consumption objects are simultaneously enacted as assests by companies, and as possessions by consumers. We argue that this ontological multiplicity means that consumers' 'possession work' no longer serves to separate these objects from the market sphere, as in prior work. This produces a new form of consumer lock-in, or actually ensnarement as it is consumers' own efforts to make objects meaningful that keep them in the market, similar to the psychological attachments seen in 'brand love', but also incorporating aspects of proprietary tie-ins, and access-based market systems. We further consider the implications of such a system. For companies we portray such ensnarement as an attractive, emerging mechanism for ongoing valorization of 'free labour'. Yet we also argue that this presents significant consequences for ensnared consumers who may be subject not only to the ongoing financial exploitation of their possession work, but also restrictions on possession. As a broader contribution we highlight how the examination of multiple, potentially conflicting, ontologies in markets may interact and shape one another.
\end{abstract}




\section{Introduction}

Alongside the material consumption objects that have long dominated consumer research we have witnessed the emergence of digital consumption objects (DCOs) which possess no enduring material substance but rather exist within digital space (computer-mediated electronic environments), accessed and consumed via devices such as desktop computers, laptops, tablets, mobile phones and videogame consoles (see Denegri-Knott and Molesworth 2010; Watkins and Molesworth 2012; Molesworth and Denegri-Knott, 2013). The objects we call our own therefore increasingly exist in digital form (Belk 2013a; Denegri-Knott and Molesworth 2010; Lehdonvirta 2012), yet present significant opportunities for profit for companies. To illustrate, in 2013, the most obvious forms of digital content accounted for $50 \%$ of UK music and video revenue, (Mintel 2014a). Indeed, DCOs also create markets for the related hardware and software involved in their consumption; the UK market for videogames consoles, for instance, is forecast to reach $£ 1.94$ billion by 2019 (Mintel 2014b). Although many DCOs are digital equivalents of material things (books, movies and music), others are new. Things like customised in-game assets, social networking profiles, bookmarks or playlists within access-based music platforms, are exemplars of a new breed of hosted DCOs and our focus here.

Within the video gaming sector there are over 110 million PlayStation network users, 65 Million Steam users and 48 million Xbox live accounts (Slashgear, 2013). On average consumers also upload 300 million images to Facebook (Armhurst 2012) and send 175 million ‘tweets’ (Mashable 2013) every day. Spotify’s 20 million subscribers have created more than 1 billion playlists to date, with over 5 million paying a monthly subscription for the service (Spotify 2013). Facebook's popularity is in a large part based on the loyalty its users attach to the content and contacts they have curated through its pages (Casadesus-Masanell \& Ricart 2011; Keen and Williams 2013). Likewise loyalty to game platforms is in part due to in-game achievements stored in users' accounts (Castranova 2008; Moon, Hossain, Sanders, Garrity \& Jo 2013). For consumers DCOs seem to become highly valued possessions, as already noted in archival practices (Kirk \& Sellen 2010), the transformation of digital commodities into meaningful possessions (Denegri-Knott, Watkins \& Wood 2012; Watkins \& Molesworth 2012), teenager's treasured digital possessions (Odom, Zimmerman \& Forlizzi 2011) and digital heirlooms (Kirk and Banks 2002). However these objects also remain assets for the companies that host them and are exploited as such. We argue that it is therefore the consumers' own possession work - the effort they put into making these objects meaningful - that entangles them in on going commercial relationships, and that these may be understood through comparisons with existing systems for maintaining tie-ins through psychological, and technological (proprietary) processes. 
We contribute to the available literature on the possession of digital goods by specifically dealing with those DCOs that are not owned by consumers in full. Having established a context in both market innovation in labour and commodity form, and critiques of production as exploited consumer labour, we offer four contributions. Firstly, we extend the scope of studies on possession in situations of non-ownership and accessbased consumption (Belk 2013a; 2013b; Bardhi, Eckhardt \& Arnould 2012; Chen 2010) complementing the language of mediation with that of networks. Drawing from Actor-Network Theory (ANT) (Latour 1993; 2005) we argue that hosted DCOs can be enacted in multiple networks simultaneously, producing conflicting ontologies whereby DCOs are concurrently enacted as assets by companies, and as possessions by consumers. Secondly, we consider the role of 'possession work' to account for the range of possession practices that consumers engage in order to enact possession of DCOs that is market mediated as a form of immaterial labour. We show how singularizing practices which elsewhere de-commoditize (Appadurai 1986; Kopytoff 1986) or sacralise mundane objects (Belk et al. 1989), tie in the co-creators of DCOs rather than sever them from the market. We (thirdly) therefore show how DCOs multiplicity produces a phenomenon of consumer ensnarement as consumers become increasingly attached to objects that cannot be separated from company influence and we compare this to other systems of market tie-in. Fourthly and finally, we consider implications for consumers. Extending existing critiques of digital prosumption, we argue that not only are ensnared consumers subject to financial exploitation, but also further restrictions may be placed upon their possession of DCOs. Overall this work highlights how the examination of multiple, potentially conflicting, ontologies in markets may interact and shape one another.

\section{Prosumption and Digital Consumption Objects in context}

Prosumption may be seen as part of a long and well-documented history of innovation in commodity form and labour exploitation and we start with this context. Early capitalism focused on the role of efficient production in producing surplus exchange value, whilst more recently the emergence of consumption dominated consumer capitalism, consumer culture (Featherstone 1991; Slater 1997) or a consumer society (Baudrillard 1998 [1970]) has been recognised, leading to the current discussions of value co-construction whereby production and consumption are performed simultaneously as consumers are 'put to work' (Zwick, Bonsu, Damody, 2008). We can look at this in two ways: the changing nature of consumption objects, and the issue of exploitation of labour in their production and as we shall see both lose materially in DCO-based business models.

Firstly we might consider the commodity form. Early in our consumer culture it became apparent that merely satisfying material needs risked the possibility of stagnation as consumers' needs became met with ever- 
greater efficiency of production, captured in the idea of Fordism. For example, Lee (2003) explains how it became desirable to move to Post-Fordist experiential commodity forms, including software that may be perpetually purchased and used up consumption. Even before the current wave of online games and social media Kline et al (2004) noted the potential for digital commodities (videogames) to represent an ideal commodity type for our era, as they expire in use and are endlessly renewed and replaced (although an emphasis in their work is the exploitation of cheap labour in the East in their production, rather than consumer labour). As a fashion system for our digital age videogames, once played and complete, are discarded in favour of the next release. A further development, and our focus, is a digital commodity form that is at least partly made by its own consumers, (and therefore for 'free'), but also and crucially for markets, remains as a corporate asset that can be valorised - used by corporations to make money - in various ways.

Secondly, companies have long benefited from customer work, with McDonald's patrons temporarily becoming unpaid waiters, and supermarket customers voluntary cashiers (Ritzer 2004). From a company's perspective the use of consumer's own labour is an attractive proposition as whilst low-paid workers produce high surplus value, the 'prosumer' generates nothing but this (Ritzer and Jurgenson 2010). The exploitation of immaterial labour, activity which 'produces the informational and cultural content of the commodity' (Lazzarato 1996, 133) to enhance the cultural and affective value of brands (see Arvidsson 2005) may be even more attractive as the physical resources required in production and distribution are further reduced. Through technology companies are therefore establishing new ways to extract value from such free labour (Terranova 2000; Bonsu and Darmody 2008; Ritzer and Jurgenson 2010). For example, Cohen (2008) considers how data uploaded to Facebook enables valorisation via surveillance and advertising revenue, whilst Bonsu and Darmody (2008) document how the owners of Second Life profit from consumers' creative input to the platform. In contemporary social media and online games, consumers also help to construct consumption objects for each other, and these objects demand further work from those involved to continue the game or social activity. For example, a Facebook user must constantly upload and share new messages, pictures and articles to maintain the interest of other users; a player of an online game must constantly work on their avatar to keep pace with new tasks, challenges and quests.

We may there understand digital consumption objects as part of a historical trajectory in capitalism where the need to maintain growth, and therefore capital flows from consumers to corporations is pressing, and results innovation in the exploitation of consumers own labour. The sorts of business models (social media, massive online games, media and content-sharing sites) that have emerged to support and encourage such 
activity may were initially presenting a resource for 'prosumers' to work with in order to create 'mutually beneficial value' (Prahalad and Ramaswamy 2000; Tapscott and Williams 2006) focused on new sources of value creation, with the consumer apparently also in a new position of control over the manufacture of value (Vargo and Lusch 2004; Tapscott and Williams 2006). Such practices have even been considered as the pinnacle of customer-centric marketing (Sheth, Sisodia and Sharma 2000), empowering consumers and creating democratized spaces of joyful collaboration in order to engage resourceful consumers (Pine and Gilmore 1999; Prahalad and Ramaswamy 2004; Vargo and Lusch 2004). The popularity of these sites, the fact that they are apparently free to use, and the enthusiasm for them from investors all seems to attest to a new type of market where value can be produced through collaboration between users and the corporations that serve them, or that they work for depending on your perspective.

The initial discourse of co-construction seems to hide the manor in which work is done and by whom, and perhaps also the consequences for something that has been at the heart of consumer culture for some time: the relationship between consumers, objects and markets. Previous work (for example, Terranova, 2000; Arvidsson, 2005; Zwick et at, 2008; Cova \& Dalli, 2009; Banks \& Deuze, 2009; Scholz, 2013) has done much to open up this critical area. Such analysis deals broadly with the concept of 'free' or 'immaterial' labour. Usergenerated content becomes part of a system where labour that is outside the factory, and therefore the direct control of companies is seen as a source of revenue for companies, but therefore also as a form of exploitation. Although users give their labour freely, and certainly get benefits other than financial ones, they lose control of their content that is then used by the company to make money. This raises questions about the 'fairness' of such an exchange, but also highlights the ability (inevitability) of capital finding new ways to extract value from the 'social factory', or an 'ethical surplus' in all the work that people do on consumption that they are not directly paid for.

We therefore favour the later commentary about co-creation movements as simply 'a veneer of consumer empowerment in a world where market power, in large measure, still resides in capital' (Bonsu and Darmody 2008, 355), such that business models reliant on the valorisation of consumers' extensive 'immaterial labour' have become central to post-Fordist capitalism (Lazzarato 1996; Hardt and Negri 2000, 2004). Here we extend such work by highlighting the multiplicity of digital consumption objects that may result in simultaneous enactments of these items as commodities/services by companies and possessions by consumers.

\section{Ontological Multiplicity and Possession Work}

Possessions and commodities are generally dealt with as largely discrete concepts in consumer 
research. Commodities are generally defined in quantitative terms in relation to their exchange value or exchangeability with other commodities (Appadurai 1986) and therefore associated with production. The singular possession is defined instead in qualitative terms by its relationship to cultural categories (Kopytoff 1986) and personal histories (Belk et al. 1989; Richins 1994). Kopytoff (1986, p.75) describes commodities as being "comparable", "having something in common with a large number of exchangeable things" in opposition to a singular possession that is "uncommon, incomparable, unique, singular and therefore not exchangeable with anything else". In order to move a commodity from its homogenising market sphere into the domain of personal possession requires self-investment (Belk et al. 1989; McCracken 1988; Richins, 1994; Wallendorf \& Arnould 1988, including work on meanings that attach an object to a time, place or other person (Csíkszentmihályi \& Rochberg-Halton, 1981) or work on customizing, cleaning, repairing, displaying and maintaining the preferential status of a meaningful or sacred possession (Belk et al. 1989).

The result is that possessions carry a patina of that work on and in them and it follows that the emotional bonding or attachment between consumers and their possessions is produced as a result of ongoing sacralisation as described by Belk et al. (1989), reflexive cultivation of psychological resources to achieve goals via the harnessing and mastery of objects (Csíkszentmihályi \& Rochbergh-Halton 1981) or their incorporation in personal and family identity projects (Belk 1988; Csikzentmihalyi \& Rochberg-Halton, 1981; Epp \& Price 2010). We can refer to this collectively as 'possession work' - the physical and especially psychological resources that consumers invest in transforming objects into possessions that cut connections to the market and at least temporarily, from exchange value. Possession work bestows objects with a singularility which, as McCracken (1988) claims, provides a visual proof of the symbolic property of an object. The dents, chips and signs of wear contribute to a possessed item's uniqueness which is difficult to fake or duplicate. However, what would this mean in the case of DCOs? Clearly they cannot carry such history with them as physical marks. Indeed, we have already suggested that they are both singular, but also commodity at the same time.

We draw from ANT to sensitise ourselves to this multiplicity. ANT suggests that realities may be multiple (Mol 1999; Law 2004). As Mol (1999) notes this is opposed to both perspectivalism that sees multiple perspectives on a singular reality, and constructivism that notes that alternative realities may have been possible at one point, but have now disappeared. ANT follows the assumption that multiple realities can be enacted simultaneously. In other words, we are not simply looking at different aspects of a single reality, but at multiple forms of reality. This is not unique to digital objects; material objects may also mean different things to different people (see Slater, 2014); a figurine may be a toy to a child but a prized collectible to an adult, a wedding dress 
may remind one consumer of their wedding day yet to a buyer on eBay the dress may simply represent a second-hand bargain. Yet in lacking materiality DCOs may have distinct instances of ontological multiplicity. Although DCOs can develop a sort of digital patina in the form of meta data that may describe their authors, any modifications made and previous use (Odom et al. 2011), and that might render them singular at one moment this may be duplicated or removed such that it does not guarantee the object's uniqueness. Unlike treasured material possessions then, DCOs can potentially be duplicated and shared any number of times, and therefore be active in different networks of possession, used and controlled by different actors. On social networking platform Facebook the same DCO (e.g. a photograph) could be interwoven with many users' profiles simultaneously via the tagging function, yet also be an asset again which Facebook sell advertising. Hence the concept of an irreplaceable, singular possession becomes problematised. Indeed it may be problematic to consider DCOs to even be the same one when they are stored on different devices and displayed on different screens as the hardware and the decoding and processing software that bring it into being would be completely different, as indeed would the very atoms that hold the zeros and ones in memory. Yet despite this, Watkins and Molesworth (2012) found that whilst exact replicas of DCOs within videogames could easily be produced, participants explained that as they would know that duplicates did not have the same history as their treasured digital virtual possessions, they would be rejected.

In the case of DCOs then, singularity is maintained in the mind of the owner and in this respect we might recognize a reversal of how agency has come to be distributed between humans and machines (for example see Denegri-Knott \& Molesworth's analysis of wish lists, 2013), and even our understanding of how material objects carry agency in this regard (Epp \& Price, 2010). Unlike material goods, the singularity of DCOs is not found in physical patina, but rather maintained in 'mental patina', as the accumulation of memories of when DCOs were first acquired, crafted or used and which are evoked each time the object is assembled regardless of hardware involved (Denegri-Knott et al., 2012; Watkins \& Molesworth, 2012). Participants' stories of 'my first avatar', 'the armour my friend gave to me or 'the car I created with my girlfriend' illustrate how the process of associating memories with particular DCOs distinguishes them even from an exact digital duplicate (Watkins \& Molesworth 2012). Hence, their possession requires on going possession work beyond initial possession rituals that require that consumers engage in or recreate the on going association of DCOs with specific individuals, times or experiences in order to experience them as singular (Watkins \& Molesworth 2012). In effect, consumers must remain diligent to the maintenance of their digital possessions once constructed. 
At the same time DCOs remain present in the networks of companies who enact them as assets and may retain the ability to act upon and change them. Our Facebook profile may become an important possession where we have invested work in cultivating meaning over many years, and yet it cannot be separated from the influence of Facebook itself who retains ownership rights over it. Thus many DCOs are not removed from the market even when made singular. Such multiplicity is typically achieved via contractual agreements that enable companies to retain a level of ownership, which in turn may be enforced by surveillance and by digital rights management (DRM) techniques (Watkins, Denegri-Knott \& Molesworth, forthcoming). Through their entanglement in software, Internet infrastructures and contractual agreements these DCOs retain an enduring presence in the market that consumers cannot sever, and so blur what might be described as a market-culture divide dominant in prior studies of material possessions in consumer research.

\section{DCOs and consumer tie-in: attachment, proprietary systems and denial of ownership}

As much Western consumption is discretionary and takes place in competitive environments, marketers have devised complex ways to maintain a customers base and here we review the characteristics of established approaches and how they might relate to DCOs. In their multiplicity, DCOs seem to present a new, and potentially highly effective, means of tying consumers into the market, based on the permanent deferral of legal ownership, (i.e., on maintaining at least some aspect of DCO in their own network of assets), whilst encouraging the further consumer work on possession (i.e, allowing the DCO to enter the consumers network of possession) that we have identified above. We may contrast this with other market mechanisms that attempt to tie consumers into market systems.

Firstly we might consider psychological loyalty to a brand, or at it's most powerful, 'brand love' that demonstrates the powerful effect of attachment in the market. Empirical insights gleaned in the study of brand love (Batra et al. 2012, Fournier 1998; Park et al. 2010) illustrate the formation of emotional attachment that requires continuous and intensive engagement with brands (Fournier 1998; Park et al, 2010). That engagement often requires market mediation of sorts - for instance, a consumer who loves his Apple iPad opts for other Apple products and services in further cultivating his relationship with his treasured device. Where there is brand love, continuous and meaningful mental and physical engagement is required (Fournier, 1998; Park et al., 2010) which is akin to those described in the literature on meaningful, sacred possession (Belk et al. 1989). In the case of customer loyalty more broadly (Liu, 2007) customers feel sufficient attachment to a brand that they continue to buy it and this idea underpins much of the marketing literature on branding and therefore considerable marketing effort (see Anderson and Mittal 2000; Morgan and Rego 2006; Liu, 2007). Brand love 
in particular frames the objectual relations between brands and consumers as intense and emotionally committed to the point that separation may cause significant distress and heartbreak (Bhatra, Ahuvia and Bagozzi, 2012). This then produces a peculiar conflation between singularizing activity and market serving outcomes as when consumers are emotionally bound to their brands they are more likely to engage in positive word of mouth (Bhatra et al., 2006; Carrol and Ahuvia, 2006; Thomas, MacInnis and Park, 2005), forgive brand failures (Bauer, Heinrich and Albrecht, 2009) and pay a price premium (Thomson, MacInnis, and Park 2005). Brand love itself, as described recently by Bhatra et al. (2006) requires 'passion driven behavior' which demands investment in branded product complements and accessories or servicing and upgrading. As with DCOs emotional attachment is positioned as a tie-in mechanism. Premium brands also benefit from consumers' work on the brand that makes it more attractive to others. So when consumers work on desirable commodities, they increase the exchange value, but also the claims for exploitation. For example we witness a form of ' double exploitation' (Zwick et al, 2008) where, fashionable clothes that are presented by consumers in public, increase their desirability, and lead to higher prices. Consumers pay a premium for their own labour in making such goods attractive. Yet consumers at least retain ownership and benefit from the strong resale values of the goods they buy.

Another long standing mechanism to retain and profit from consumers is through loyalty schemes which reward continued patronage with points, prizes, money-off offers or vouchers (Liu, 2007; Zhang and Breugelmans, 2012), such as those popular with supermarkets and retail chains in the UK. Liu (2007) for instance concludes that loyalty programs increase purchasing from low patronage consumers. Other studies conclude that reward-based loyalty programmes tie new customers into repeat purchasing and increase patronage from existing customers (Evanschitzky et al., 2012; Meyer-Waarden and Benavent, 2006), lower price sensitivity (Guadagni and Little, 2008), increase price levels for brands (Chaudhuri and Holbrook, 2001) and increase sales revenue (Meyer-Waarden and Benavent, 2006; Zhang and Breugelmans, 2012). Cast with a critical eye, as does Beckett (2011) in his study of a loyalty card in a leading UK supermarket, loyalty programs can be seen as tantamount to means of governing consumers purchasing behavior via continuous surveillance and through carefully incentivized schemes. Loyalty schemes themselves become objects of consumption as individuals collect and possess points, vouchers and offers that can only be used with the loyalty platform provider. As with DCOs then, here then we see a tie-in based on a proprietary platform and consumers 'want' to keep working on and we might also note the similarity between 'gamified' loyalty that places an emphasis on 
accumulated points and the mirco-level structures of online games and social media that similarity emphasise scores, levels and status-based achievements (e.g., see Molesworth and Watkins, 2014)

Yet other means of tying-in and profiting from customers are based on proprietary systems for consumption objects themselves (Zhu and Zhou, 2011). Such systems produce a 'vendor lock in', where customers, unwilling to pay high switching costs, are forced into a continued relationship with a software or hardware provider. Customers are tied in because of inbuilt incompatibility between software and hardware manufacturers, the use of proprietary systems architecture that is inoperable with other applications, and through licensing agreements which limit use (Kucharik, 2003). Printer cartridges, computer accessories, or camera lens, for example, must be licensed from the original manufacture and such systems may be protected through IP legislation, but actually may be enforced through code. For example, printer cartridges may require a code encrypted in a microchip and only placed in authorized goods to work. Consumers are therefore forced to continue to buy only the manufactures' or licensed products. For companies, such lock-ins provide lucrative opportunities for cross-selling, increased revenue from customers and protection against competitors (Amit and Zott, 2001; Farrell and Klemperer, 2007; Harrison, Beatty, Reynolds, and Noble, 2012). Again, as with DCOs, for consumers, such systems erode freedom of choice and can diminish the quality of the experience with software and hardware (Eurich and Burtscher, 2014).

These systems all encourage 'loyalty' of sorts through physical and psychological attachment to brands where ownership remains encouraged. More recently however, the role of market mediation in possession has been reframed through the idea of 'access-based' consumption (Bhardi et al. 2012; Bardhi \& Eckhardt, 2012; Chen, 2010). Here consumers pay a premium to access a consumption object for a limited time and in a restricted fashion. Most obviously this applies to anything that is rented or leased, such as cars or apartments, but the model is being more widely adopted, and celebrated as liberating consumers from the burden of work required to maintain possessions (Bhardi et al. 2012; Bhardi \& Eckhart 2012), for example, a Zipcar may be used only as needed, without time-consuming maintenance, or cleaning and without the psychological worries of car possession (fear of damage, breakdown, or theft). However without owning the consumer must keep paying for the service and indeed may be tied in for a term of a contract (for example in car leasing).

Assess-based consumption represents a shift in market philosophy away from consumer possession work, the avoidance of which is now seen as a premium service. Yet in DCOs we see that the desire for attachment remains. The 'trick' with DCO-based platforms is to maintain processes of attachment whilst also separating ownership such that sacred possessions become the objects of access. DCOs therefore represent a 
combination of psychological tie-in and attachment, proprietary rewards and systems, and a separation that requires on going payment for access (see Table 1). Both access to the DCO and the possession work required to create and enact possession are therefore market mediated. For example, in previous research, the creation and maintenance of meaningful DCOs is said to be performed via skilled manipulation of in-game resources (Denegri-Knott et al. 2012), all facilitated by the host videogame company. The cultivation process itself cannot be severed from the market because it is hosted by it, and because the means necessary to customise a DCO, like a home in The Sims or a racing car in Forza are embedded in the market. Singularising work thus can be said to be equally commoditising inasmuch as it fails to sever ties with the market and because consumers' emotional attachment towards DCOs makes these important assets for hosting companies. Differently put the work done by consumers in order to create and enact possession of DCOs is 'immaterial labour', the type of work that dominates information-based economies more generally like creative, design, emotions and social interactions (for example see Scholz, 2012) and such possession work contributes significantly to both the use value (which is largely located in their meanings to users) and exchange value of hosted DCOs.

If we consider as an example social media accounts, although the host companies provide the infrastructure within which consumers may create their profiles, own the servers on which they are hosted and pay the website developers who create and maintain the platform, the value of these websites ultimately lies in consumers' extensive possession work. It is the user who uploads and tags multiple photographs, fills out personal information, and continuously provides the up-to-date and socially valuable information that makes websites such as Facebook a success. This possession work involves an on going investment of psychic energy (Csíkszentmihályi \& Rochberg-Halton 1981). Consumers’ creation and cultivation of their social media platforms presents a major contribution to the use value of these objects, and thus also exchange value - the companies' revenue - as they sell advertising associated with the profile.

Where there is no possession work, the status of these consumption objects is likely to be transparently based only on access (Bhardi \& Eckhardt, 2012) the financial exchange may be temporary, but unproblematic. However, where the consumer invests considerable effort to cultivate a DCO the character of the relationship may be different and this invites us to consider the consequences of these business models and the subsequent denial of legal ownership upon the possession of hosted DCOss. To put it another way, although issues of (the potential exploitation of) labour are significant for new business models, such analysis might also consider structures of meaning that may be embedded in objects. In contrast to acquired, 'mass-produced' DCOs, and almost all mass-produced material goods, DCOs that are created by consumers are uniquely brought into 
existence by consumers' labour, and immediately multiple as they simultaneously exist as an asset for the hosting organisation. The result is form of 'consumer ensnarement' where it is the consumers own labour that keeps them in the market and prevents the separation reported for material goods.

With DCOs we witness a mechanism that allows for a 'vendor lock in' possible through proprietary systems and reward-based schemes, but which is not solely dependent on code restrictions but rather operates through emotional bonding akin to 'brand love'. Unlike 'brand love', however DCOs require continuous engagement with the market in order to access their 'own' co-created DCOs. Companies in providing co-created DCO hosted online like social media profiles and MMORGs benefit from a peculiar type of prosumption workpossession work - that produces conflicting ontologies whereby a cherished DCO is simultaneously an asset for the companies hosting them. The benefits for corporations seem clear; consumers are ensnared by their own efforts, as their identity-rich possession work remains owned by the corporation that may then charge for access. However, we must now consider the further implications of such a system for consumers.

\section{Consequences of Ensnarement for Consumers: Exploitation, Restriction and Instability}

Prior scholarship has discussed the potential for prosumer reliant online business models to exploit consumer labour (Terranova 2000; Bonsu and Darmody 2008; Ritzer and Jurgenson 2010). However the ontological multiplicity of hosted digital consumption objects presents further consequences for consumers that have yet to be fully recognized and that are also summarised in Table 1.

One consequence of ensnarement as a valorisation mechanism is demonstrated by Watkins and Molesworth's (2012) study of videogamers' digital possessions. Speaking to players of massive multiplayer online games (MMOGs) they report instances where individuals had invested significant time and effort on DCO possession work during their teenage years playing various online games, creating unique characters and collecting and singularising in-game content. One of their participants, for instance, described a strong emotional attachment to her first World of Warcraft avatar. Yet the avatar remains hosted by World of Warcraft provider Blizzard, assembled by the company as an asset, and part of the service that they provide. Consequently, regardless of the avatars enactment by this consumer as a treasured and irreplaceable possession, we note that this avatar retains its link to the market sphere. This can hold significant consequences for consumers. Watkins and Molesworth (2012) note that whilst some participants had not played the videogames they discussed for a number of years, they continued to pay monthly subscription fees in order to retain access to goods that they themselves had largely created. Here we see evidence of ensnarement as consumers invest 
effort in making possession meaningful, tying themselves into a platform, yet must repeatedly pay subscription fees in order to retain access.

Comparison here might help highlight how this diverges from previous literature on similarly rich possession work in the context of material consumption objects (Campbell 2005; Watson and Shove 2008). Like the hosted DCOs discussed above which are in part produced by consumers themselves, material items may too be crafted through consumers' own labour, and research indicates that such crafting leads consumers to value these possessions highly (Campbell 2005). Let us imagine for instance the task of crafting a small wooden coffee table as a DIY project. Although the craft consumer may buy wood, tools and even instructions through market exchange, once made the table will be theirs to use as they wish. More than this, their invested labour may result in this table becoming an important possession. Indeed such crafting might be seen as very different from the alienated consumption of mass produced furniture, or even the exploited consumer labour of selfassembly goods (where consumers' labour is used rather than even the cheapest overseas factory workers, but where little craft is involved). The crafted coffee table is not simply possessed through ritual (McCracken, 1986) or through the development of meaningful associations over time (Grayson and Schulman 1990), but emerges as the product of consumers' own labour and expression of their identity (Campbell 2005).

Now imagine that after laboriously crafting their new piece of furniture the consumer would be required to continually pay the logging company that supplied the wood in order to continue to use this table, and that if they refuse to pay the company will restrict access. This is difficult to comprehend in the context of material objects yet in the context of hosted digital consumption objects such practices are commonplace. Here companies do not only charge consumers a surplus for the products of their own labour, but the more possession work consumers invest into the cultivation of such goods the more valuable they may become to them. Under such circumstance it may become difficult to escape the market; like an animal in a snare the consumer is kept trapped by their own efforts. This is particularly problematic where consumers are continually charged for access to the platform, as in the case of many MMOGs like World of Warcraft. Here consumers may be forced to choose between either indefinitely paying for access to 'their' goods, or abandoning these treasured possessions altogether. Indeed, it is not only the game provider that must be paid to ensure access. Consumers must also continue to pay for internet access and for the hardware (e.g. computers, monitors) needed to assemble DCOs. Again material comparisons seem ridiculous. Returning to the metaphor of the coffee table, this might be equivalent to this item embroiling the consumer in on-going contracts with the logging company, tool manufacturers and even the retailer that sold the wood and tools. 
Online platforms provide consumers with the freedoms that enable and even encourage possession work, inviting consumers to transform hosted digital consumption objects into meaningful possessions. Videogames may provide extensive customization options, for example, or enable practices of sharing and gifting of certain in-game items that associate these items with important others (again see Watkins and Molesworth 2012). Similarly Facebook provides consumers with the ability to easily post statuses and upload large numbers of photographs and videos to the platform, and also enables consumers' friends to 'comment' on this content; Odom et al (2011) find that this accumulation of 'metadata' such as 'comments' and 'likes' can serve as 'digital patina' which makes content increasingly valued. Virtual world Second Life goes further and provides consumers with IP rights to their creations within the platform, something which Bonsu and Darmody (2008) propose mobilizes consumer labour via the 'guise' of empowerment. Furthermore, we see can observe instances of companies actively encouraging consumers' to engage in meaningful, long-term relationships with hosted digital consumption objects. For instance in 2011 Google released an advertisement featuring a father sending anecdotes, photographs and videos to his daughter throughout her childhood via Google's email service, with the intention of one day reflecting on these emails together (Bazilian, 2011) - here Google invites users to use its email service create treasured digital scrapbooks. Similarly in March 2015 Facebook announced the launch of a new scrapbooking feature that enables parents to gather together photographs of their children from across the platform into one album or 'scrapbook' that can be continually added to as the child grows (Chowdrhy 2015). Thus platforms actively encourage meaningful possession work that transforms hosted digital consumption objects into treasured digital possessions with significant personal and often highly sentimental meaning. Yet in order to successfully extract value companies also impose limits to use that are often taken for granted in the context of material possessions.

In order to effectively and continuously extract value from consumers' possession work companies impose technical (code) and legal (End-User License Agreements) boundaries around customer freedoms whilst maintaining those practices that lead to possession. Such restrictions may be placed on the movement of digital objects between consumers, for instance. Much consumer research considers the movement and exchange of material goods, often facilitated by consumers who move goods from one stage of their biography to the next. For example, research has explored the significant second hand market fuelled by material goods repeatedly reentering the commodity sphere (Gregson and Crewe 2003; Sherry 1990; Belk, Sherry and Wallendorf 1988; Lastovicka and Fernandez 2005; Denegri-Knott and Molesworth, 2009), as well as documenting the passing on of family heirlooms (Price, Arnould and Curasi 2000) and practices of giving our possessions to, and sharing 
them with, family and friends (Belk 2010; Tinson and Nuttall 2008). However many such practices documented lack a DCO equivalent. The ability to transfer either accounts or individual hosted digital consumption objects (such as in-game assets) to others may be denied in services' terms and conditions (see for instance Facebook 2015; Instagram 2015; Blizzard 2013), resulting in a 'terminal commodity' status that may prevent not only reentry to the market via re-commodification, but also acts of passing items to friends or family. Whilst it is common to pass on a treasured childhood toy to decedents, parents may be prohibited from similarly passing down a treasured avatar or gaming account to their child. World of Warcraft's Terms of Use, for instance, state that it 'does not recognize the transfer of World of Warcraft Accounts [...] You may not purchase, sell, gift or trade any Account' (Blizzard, 2014). Attempting to pass down a treasured World of Warcraft avatar would breach the service's Terms of Use. Thus as consumers accumulate cherished, personally meaningful possessions both scholars and consumers are beginning to consider the notions of digital heirlooms and digital legacy (Carroll and Romano 2010; Odom et al 2010, 2012). Here we see that consumers may be denied the control central to our understanding of possession (Furby 1978; Belk 1988); granted only those freedoms favourable to the company.

Although transfer practices may frequently be 'forbidden', this does not necessarily mean that they do not take place. For instance, a look at popular video gaming forums reveals contributors planning to pass on their accounts to friends or family, or admitting to sharing an account with their partner, despite recognising that such actions are prohibited by contractual agreements. Yet these activities, established and normal for material goods, breach contractual agreements such that consumers risk losing access to content, particularly given increased potential for companies' on-going surveillance of use and so the more consumers invest meaning and value in hosted digital consumption objects the more agency companies' ownership configurations come to hold over consumers' behaviour. Thus, whereas Bardhi et al (2012) position digital consumption objects as liberating consumers from the burdens of material possession, we draw attention to the restrictive aspects of them which render consumers unable to control or exploit fully even the products of their own labour.

Further consequences relate to the absence of the security provided by legal ownership, potentially resulting in a tense and unstable possession. Companies such as Facebook (2015), Instagram (2015) and World of Warcraft (Blizzard 2014) stipulate in their contractual agreements that they retain the right to terminate users' accounts and thus eliminate their right to their profile and the content they have uploaded and cultivated. World of Warcraft provider Blizzard, for example, retains the right to terminate accounts 'for any reason or no reason, with or without notice' (Blizzard 2014). Termination may be due to the consumers' violation of the company's 
terms, but might also result from the company's collapse, or technical error. Watkins and Molesworth (2012) note that the publishers of MMOGs typically retain the right to terminate the service without notice, and in doing so eradicate consumers' achievements, avatars and in-game possessions without a trace, whilst Bonsu and Darmody (2008) note that the same is true in the case of Second Life. Thus the contractual agreements involved in such platforms places companies under no obligation to continually host the digital consumption objects in question. Indeed platform closures have been previously documented. For instance, Scarabato, Carter-Schneider and Kedzior (2013) illustrate that in investing significant labour in Disney's adverworld 'Virtual Magic Kingdom' users developed a sense of co-ownership and an assumption of continued access, however Disney later terminated the platform (and consequently consumers' hosted content) and were within their legal rights to do so. Pearce and Artemesia (2009) document a similar instance of loss, documenting the experiences of selfproclaimed 'refugees' following the closure of their game world, 'Uru: Ages Beyond Myst'.

As a result the continued possession of $\mathrm{COs}$ is never certain. For example, although around $5 \%$ of babies under two are estimated to have a social media profile (AVG 2010), with new parents religiously uploading treasured photographs and messages to be read in years to come, consumers cannot rest assured that these lovingly crafted digital scrapbooks will remain available. Their lack of permanence again leads us to consider how such meaningful relationships with unstable digital virtual possessions may relate to consumer identity projects. Belk (1988) notes the potential for significant 'lessening' of the self where highly appropriated possessions are lost. As hosted DCOs remains reliant on the persistence of their host websites, over which the consumer has no control, the result may be tense and stressful in comparison to the possession of material goods. Again we see that consumers are granted those consumer freedoms that encourage possession work that benefits companies as immaterial labour, yet lack those rights that are traditionally associated with material possessions including permanent rights to use and access these items that provides a level of security.

\section{Discussion and conclusions}

Digital consumption objects can be both representative of possession work as they are crafted and made meaningful by consumers, but also and elsewhere owned by corporations as assets to be valorised, although this latter status is often 'manifest absent' such that consumers do not realize the snare until they are already entangled. In effect we see structural conflation of the cultural aspects of consumption (the aspects of consumption that relate to use value and that involve meaning cultivation) and the commercial aspects of 
consumption (where exchange value is produced and extracted). We summarise our previous sections in Table

1.

Table 1 Market/consumer tie-in systems

\begin{tabular}{|c|c|c|c|c|}
\hline System & Examples & Mechanisms & Implications for business & Implications for consumers \\
\hline $\begin{array}{l}\text { Psychological } \\
\text { loyalty/Brand } \\
\text { love }\end{array}$ & $\begin{array}{l}\text { Apple/ luxury } \\
\text { brands }\end{array}$ & $\begin{array}{l}\text { Attachment to brand, } \\
\text { association with positive } \\
\text { aspects of identity. Consumers } \\
\text { publicly work on brand making } \\
\text { it desirable for others }\end{array}$ & $\begin{array}{l}\text { Consumer desire for latest } \\
\text { products at premium price. } \\
\text { Consumers work on brand } \\
\text { to make it desirable }\end{array}$ & $\begin{array}{l}\text { Potential of double } \\
\text { exploitation. Identity work and } \\
\text { benefit of resale value when } \\
\text { goods divested }\end{array}$ \\
\hline $\begin{array}{l}\text { Proprietary } \\
\text { hardwarel } \\
\text { software }\end{array}$ & $\begin{array}{l}\text { Microsoft/ } \\
\text { Computers/Printers/ } \\
\text { DSLRs/ }\end{array}$ & $\begin{array}{l}\text { Only groups of products } \\
\text { authorized by brand work } \\
\text { together, maintained by } \\
\text { physical and/or software } \\
\text { restrictions. }\end{array}$ & $\begin{array}{l}\text { Prevents unauthorized } \\
\text { copies and ties consumer } \\
\text { to group of products }\end{array}$ & $\begin{array}{l}\text { Decision over initial platform } \\
\text { has longer-term implications. } \\
\text { Tied in, but can change to } \\
\text { another platform at cost }\end{array}$ \\
\hline $\begin{array}{l}\text { Offer-based } \\
\text { loyalty } \\
\text { scheme }\end{array}$ & $\begin{array}{l}\text { Tescol } \\
\text { retailer, or airline } \\
\text { loyalty schemes }\end{array}$ & $\begin{array}{l}\text { Small financial incentive given } \\
\text { to consumer in return for } \\
\text { continued use of service and } \\
\text { surrender of data. Game-like } \\
\text { structure. Proprietary } \\
\text { platform }\end{array}$ & $\begin{array}{l}\text { Value of data collected and } \\
\text { consumers tied-in to } \\
\text { scheme, but surrender of } \\
\text { small part of exchange } \\
\text { value }\end{array}$ & $\begin{array}{l}\text { Small return of exchange value } \\
\text { as payment for loyalty and } \\
\text { data. Can stop at any time, but } \\
\text { will lose accrued benefits. } \\
\text { Cannot transfer to another } \\
\text { scheme. }\end{array}$ \\
\hline $\begin{array}{l}\text { Access-based } \\
\text { consumption }\end{array}$ & $\begin{array}{l}\text { Zip-Car/lease car, } \\
\text { online subscription }\end{array}$ & $\begin{array}{l}\text { Goods are never transferred } \\
\text { to consumer, who pays a small } \\
\text { amount only for the access to } \\
\text { the goods that they require, } \\
\text { when they require them }\end{array}$ & $\begin{array}{l}\text { Business retains } \\
\text { ownership, and the labour } \\
\text { that goes with that, but gets } \\
\text { ongoing revenue }\end{array}$ & $\begin{array}{l}\text { Liberated from the need to } \\
\text { work on possession, flexible } \\
\text { exchange of capital for access. } \\
\text { Going payment for service. }\end{array}$ \\
\hline $\begin{array}{l}\text { Co-creation } \\
\text { of DCOs }\end{array}$ & $\begin{array}{l}\text { Facebook/ } \\
\text { online games/UGC } \\
\text { platforms }\end{array}$ & $\begin{array}{l}\text { Attachment to brand through } \\
\text { possession work. Separation of } \\
\text { possession from ownership. } \\
\text { Goods are never transferred } \\
\text { to consumer. Software } \\
\text { restrictions. Proprietary } \\
\text { platform. }\end{array}$ & $\begin{array}{l}\text { Consumers work on the } \\
\text { object they consume. Can } \\
\text { continue to charge for } \\
\text { access, and or value of data } \\
\text { collected. May prevent } \\
\text { divestment with code. }\end{array}$ & $\begin{array}{l}\text { Identity work, but must } \\
\text { continue to pay or work for } \\
\text { corporation in order to retain } \\
\text { access, or will lose possessions } \\
\text { and forfeit all payments DCOs } \\
\text { Lack of security and control of } \\
\text { objects }\end{array}$ \\
\hline
\end{tabular}

In many cases DCOs are uniquely the product of consumers own efforts, their unpaid labour as they work not for exchange value, but for meaning. In others DCOs emerge as gifts, for example in the case of shared messages, photographs, and in game assets. These are forms of exchange we would normally associate with practices that are outside the market. Crafting, sharing and gifting, at least in prior consumer research literature (Belk 2010; Campbell 2005; Sherry 1983), are typically activities where individuals give their time, knowledge and skill freely and without thought of exchange value. Yet through new business models these practices may be carefully captured and valorised. They are therefore not just the exploitation of small amounts of free labour (as with self-service shops and restaurants, or self-assembled furniture), but the skilful exploitation of efforts to produce and share meanings outside of markets; a particularly creative solution to the established Post-Fordism problem of the need to maintain growth. Rather than endlessly stimulating desire for new goods, or exploring elaborate ways to maintain share over competitors in saturated markets, markets associated with DCOs are able to continue to both charge consumers for their own meaningful work, and for the technological tools and service required to access the objects created. 
In prior literature there has been a tendency to separate the states of possession and commodity, and the spheres market and culture, with consumers' possession work severing ties between an object and its market origins, including exchange value (Kopytoff 1986). In this article, however, we have seen that digital consumption objects exhibit an ontological multiplicity whereby rather than separating hosted digital consumption objects from the market sphere, possession work instead produces a phenomenon of consumer ensnarement, tying consumers to items which can't be separated from the company's influence. As consumer play various online games and engage with social media their work on meaning and identity is owned and exploited by corporations.

Our analysis also contributes to understandings complex consumer tie-in mechanisms. We see that consumer ensnarement presents a valorisation mechanism that combines characteristics of: (1) the psychological loyalty that exploits and encourages immaterial labour as consumers work on desirable goods; (2) aspects of points-based rewards (in the form of game levels, likes and status markers in social networks, and in the use of consumer data, for example); (3) proprietary systems that prevent consumers using consumption objects on or with another corporation's platform, and; (4) access-based systems where a continuous payment is required. We might therefore recognise digital consumption objects as something of an ideal commodity form of the web 2.0 era, enabling companies to continually profit from consumers' own immaterial labour.

Our analysis therefore adds to emerging critiques of 'value-co-creation' and 'service-dominant logic' perspectives (Cova and Dalli 2009; Zwick et al 2008; Bonsu and Darmody 2008) by exploring the implications of prosumer reliant online business models on the possession of DCOs. As a result of this inability to escape the market consumers must deal with the tension that arises where hosted digital consumption objects are possessed but not legally owned, and in some cases consumers may be forced to choose between either abandoning treasured digital virtual possessions or continuing indefinitely to pay for access to goods that they themselves largely created. We see how such markets not only exploit consumers' immaterial labour for financial gain, and may proceed to charge them a surplus for the fruits of their own labour, but once purchased the consumers are denied full control over the DCOs they have worked so hard to cultivate. Thus, whilst some propose that prosumption may not involve exploitation where consumers benefit from this activity, we note that with DCOs such business models have further consequences which must be considered.

More broadly we demonstrate the consequences of the relation of multiple ontologies; it is through consumers' enactment of DCOs as possessions that consumer ensnarement becomes a valorisation mechanism for companies, whilst it is through the enactment of digital consumption objects as commodities or services that 
consumers are subjected to exploitation and to restrictions upon their possession of these objects. Thus this paper not only recognizes ontological multiplicity but also theorizes ways in which multiple, potentially conflicting, market realities may interact and shape one another.

\section{References}

Amit, R., \& Zott, C. (2001). Value Creation in E-Business. Strategic Management Journal, (6/7). 493.

Anderson, E. W. and Mittal, V. (2000). Strengthening the Satisfaction-Profit Chain, Journal o $f$ Service Research, 3 (2). 107-120.

Appadurai A. (1986). The Social Life of Things: Commodities in Cultural Perspective. Cambridge University Press: Cambridge.

Arvidsson, A. (2005). Brands: A critical perspective. Journal of Consumer Culture, 5, 235-258.

AVG, (2010). Would you want a digital footprint from birth? http://blogs.avg.com/view-from-the-top/wouldyou-want-a-digital-footprint-from-birth/

Banks, J. and Deuze, M. (2009). Co-creative labour. International Journal of Cultural Studies, 12(5), 419-431.

Bardhi, F. \& Eckhardt, G.M. (2012). Access-Based Consumption: The Case of Car Sharing. Journal of Consumer Research, 39(4). 881-898. doi 10.1086/666376

Batra, R., Ahuvia, A., \& Bagozzi, R. P. (2012). Brand Love. Journal of Marketing, 76(2). 1-16

Baudrillard, J., 1998[1970]. The Consumer Society. London: Sage

Bauer H., Heinrich D. and Albrecht, C-M. (2009). All you need is love: assessing consumers' brand love, American Marketing Association Summer Educators' Conference, Chicago

Bazilian, E. (2011, May 14). Google Kicks Off TV Campaign to Promote Chrome- Ads tug at heartstrings of Internet users. Adweek. Retrieved from: http://www.adweek.com/news/advertising-branding/google-kicks-tvcampaign-promote-chrome-131322

Beckett A (2012), Governing the consumer: technologies of consumption, Consumption, Markets \& Culture, Vol 15, Iss 1, p1-18

Belk, R.W. (2010). Sharing. Journal of Consumer Research, 36 (February), 715-34. doi: 10.1086/612649

Belk, R.W. (2013a). Extended Self in a Digital World. Journal of Consumer Research, 40(3). 477-500. doi: 10.1086/671052

Belk, R.W. (2013b). You are what you can access: Sharing and collaborative consumption online. Journal of Business Research, 67(8). 1595-1600. doi: 10.1016/j.jbusres.2013.10.001

Belk, R.W., Sherry Jr., J., and Wallendorf, M., (1988). A Naturalistic Inquiry into Buyer and Seller Behavior at a Swap Meet. Journal Of Consumer Research, 14 (4), 449-470.

Belk, Russell W. (1988), "Possessions and the Extended Self," Journal of Consumer Research, 15 (September), 139-68.

Blizzard (2014). World of Warcraft End User Licence Agreement. Retrieved from http://us.blizzard.com/en- 
us/company/legal/wow_eula.html

Bonsu, S.K. and Darmody, A., (2008). Co-creating Second Life: Market-consumer co-operation in contemporary economy. Journal of Macromarketing, 28(4), 355-368.

Campbell, C., (2005). The Craft Consumer: Culture, craft and consumption in a postmodern society. Journal of Consumer Culture, 5(1) 23-42.

Carroll, B. A., \& Ahuvia, A. C. (2006). Some Antecedents and Outcomes of Brand Love. Marketing Letters, (2). 79

Carroll, E. and Romano, J. (2010). Your Digital Afterlife: When Facebook, Flickr and Twitter Are Your Estate, What's Your Legacy? Berkeley, CA: New Rider's Press.

Casadesus-Masanell, R., \& Ricart, J. E. (2011). How to Design A Winning Business Model. Harvard Business Review,89(1/2). 100-107.

Castronova, E. (2005). Synthetic worlds: The business and culture of online games. Chicago: University of Chicago Press.

Chaudhuri, A. \& Holbrook, M. (2001). The Chain of Effects from Brand Trust and Brand Affect to Brand Performance: The Role of Brand Loyalty, Journal of Marketing, 65 (April). 81- 93.

Chen, Y. (2009). Possession and Access: Consumer Desires and Value Perceptions Regarding Contemporary Art Collection and Exhibit Visits. Journal of Consumer Research, 35 (April). 925-40. doi: 10.1086/593699

Chowdrhy, A. (2015). Facebook Launches A New Scrapbook Feature To Keep Photos Of Your Children Organized. Available from: http://www.forbes.com/sites/amitchowdhry/2015/03/31/facebookscrapbook/ [Accessed 2 April 2015]

Cohen, N. S., (2008). The Valorization of Surveillance: Towards a Political Economy of Facebook. Democratic Communiqué, 1, 5-22

Cova, B. and Dalli, D. (2009). Working consumers: the next step in marketing theory? Marketing Theory, 9(3), 315-339.

Czikszentmihalyi, M. \& Rochberg-Halton, E. (1981). The Meaning of Things: Domestic Symbols and the Self. Cambridge, MA: Cambridge University Press.

Denegri-Knott, Janice and Molesworth, Mike (2009) "I'll sell this and I'll buy them that": eBay and the management of possessions as stock. Journal of Consumer Behaviour, 8, (6), 305-315

Denegri-Knott, J. \& Molesworth, M. (2010). Concepts and Practices of Digital Virtual Consumption. Consumption, Markets \& Culture, 13(2). 109-132. doi: 10.1080/10253860903562130

Denegri-Knott, J \& Molesworth, M (2013) Redistributed consumer desire in digital virtual worlds of consumption. [in special issue: Virtual Worlds] Journal of Marketing Management, 29, (13-14), 1561-1579.

Denegri-Knott, J., Watkins, R. \& Wood, J. (2012). Transforming Digital Virtual Goods into Meaningful Possessions. In M. Molesworth \& J. Denegri-Knott (Eds.). Digital Virtual Consumption (pp. 76-91). Oxford: Routledge.

Epp, A., \& Price, L. (2010). The Storied Life of Singularised Objects: Forces of Agency and Network Transformation. Journal of Consumer Research, 36(5). 820-837. doi: 10.1086/603547

Eurich, M., Weiblen, T., \& Breitenmoser, P. (2014). A Six-step Approach to Business Model Innovation. 
Evanschitzky, H. Ramaseshan, B, Woisetschläger, D M, Richelsen, V Blut, M, \& Backhaus, C (2012) Consequences of customer loyalty to the loyalty program and to the company, Journal of the Academy of Marketing Science, 40 (5) 625-638.

Facebook, (2015).Terms. Available from: http://www.facebook.com/legal/terms [Accessed 12 February 2015].

Farrell, J., \& Klemperer, P. (2007). Coordination and Lock-in: Competition with Switching costs and Network Effects. Handbook Of Industrial Organization, 3, 1967-2072.

Featherstone, M. (1991). Consumer Culture and Postmodernism. London: Sage

Fournier, S. (1998). Consumers and Their Brands: Developing Relationship Theory in Consumer Research. Journal of Consumer Research, 24(4). 343-373.

Furby, L., (1978). Possession in humans: an exploratory study of its meaning and motivation. Social Behavior and Personality: an International Journal, 6(1), 49-65.

Grayson, K. \& Schulman D. (2000). Indexicality and the Verification Function of Irreplaceable Possessions: A Semiotic Analysis. Journal of Consumer Research, 27(June), 17-30. doi: 10.1086/314306

Gregson, N. and Crewe, L. (2003). Second Hand Cultures. Oxford, UK: Berg.

Guadagni, P. M. \& Little, J. (2008). A Logit Model of Brand Choice Calibrated on Scanner Data, Marketing Science, 27 (1). 2948.

Hardt, M. and Negri, A., (2000). Empire. Cambridge, Mass: Harvard University Press

Hardt, M. and Negri, A., (2004). Multitude: War and Democracy in the Age of Empire. New York: Penguin Press.

Harrison, M. P., Beatty, S. E., Reynolds, K. E., \& Noble, S. M. (2012). Why Customers Feel Locked Into Relationships: Using Qualitative Research to Uncover The Lock-in Factors. Journal Of Marketing Theory \& Practice, 20(4), 391-40

Instagram, (2015). Terms of Use. Available from: http://instagram.com/about/legal/terms/ [Accessed 14 February 2013].

Keen, P., \& Williams, R. (2013). Value architectures for digital business: beyond the business model. MIS Quarterly, 37(2). 643-647

Kirk D \& Sellen A. (2010). On Human Remains, Values and Practice in the Home Archiving of Cherished Objects. Transactions on Computer-Human Interaction 17(3): 1-43.

Kirk D. \& Banks R. (2008) On the Design of Technology Heirlooms. In Proceedingsof the International Workshop on Social Interaction and Mundane Technologies (SIMTech'08).

Kline S, Dyer-Witheford N and De Peuter G (2003) Digital Play: The Interaction of Technology, Culture, and Marketing. Montreal, QC, Canada: McGill-Queen's University Press.

Kopytoff, I. (1986). The cultural biography of things, commoditization as a Process in The Social Life of Things Commodities in a Cultural Perspective, Arjun Appadurai (ed.). Cambridge University Press: Cambridge: 64-94.

Kucharik, A. 2003.2 Vendor lock-in. http://searchopensource.techtarget.com/qna/0,289202,sid39_gci913129,00.html. 
Lastovicka, J.L., and Fernandez, K.V., (2005). Three Paths to Disposition: The Movement of Meaningful Possessions to Strangers. Journal of Consumer Research, 31(March), 813-832.

Latour B. (1993). We Have Never Been Modern. Hertfordshire: Harvester Wheatsheaf.

Latour, B. (2005). Reassembling the Social: An Introduction to Actor-Network Theory. Oxford, UK: Oxford University Press

Law, J (2004). After Method: Mess in Social Science Research. London: Routledge

Lazzarato, M., (1996). Immaterial Labor (Translated by P. Colilli and E. Emery). In: Hardt, M. and Virno, P., eds., Radical Thought in Italy: A Potential Politics. Minneapolis: University of Minnesota Press, 133-147.

Lee MJ (1993) Consumer Culture Reborn: The Cultural Politics of Consumption. London: Routledge

Lehdonvirta, V., (2009). Virtual Item Sales as a Revenue Model: Identifying Attributes that Drive Purchase Decisions. Electronic Commerce Research, 9(1), 97-113.

Liu, Y. (2007). The Long-Term Impact of Loyalty Programs on Consumer Purchase Behavior and Loyalty. Journal Of Marketing, 71(4). 19-35.

Mashable (2013). The Internet In 2012: 634 Million Websites, 2.4 Billion Users. Available from: http://mashable.com/2013/01/17/the-internet-in-2012-634-million-websites-2-4-billion-users-1-3-trilliongoogle-searches/ [Accessed 12 February 2013].

McCracken, G. (1986). Culture and Consumption: A theoretical account of the structure and movement of the cultural meaning of consumer goods. Journal of Consumer Research, 13(June), 71-84. Retrieved from: http://www.jstor.org/stable/2489287

McCracken, G.D. (1986). Culture and Consumption, New Approaches to the Symbolic Character of Consumer Goods and Activities. Indiana University Press: Bloomington, IN.

Meyer-Waarden, L. \& Benavent, C. (2006). The Impact of Loyalty Programmes on Repeat Purchase Behaviour, Journal of Marketing Management, 22 (February). 61-88.

Mintel, 2014a. Music and Video Purchasing - UK - August 2014.

Mintel, 2014b. Videogames and Consoles - UK - November 2014

Mol, A. (1999). Ontological Politics: a Word and Some Questions. In J. Law and J. Hassard (Eds.) Actor Network and After. Oxford and Keele, Blackwell and the Sociological Review: 74-89. How are worlds, realities, performed into being? This is an ANT question. Here an 'ontological politics' is imagined.

Molesworth, M and Denegri-Knott, J (2013) Digital virtual consumption as transformative space. In, Belk, Russell W. and Llamas, Rosa (eds.) The Routledge Companion to Digital Consumption. Abingdon, GB, Routledge, 223-234.

Molesworth, M and Watkins, R (2014) Adult videogame consumption as individualised, episodic progress. Journal of Consumer Culture. (doi:10.1177/1469540514528195).

Moon, J., Hossain, M., Sanders, G., Garrity, E., \& Jo, S. (2013). Player Commitment to Massively Multiplayer Online Role-Playing Games (MMORPGs): An Integrated Model. International Journal Of Electronic Commerce, 17(4). 7-38.

Morgan, N. A. \& Rego, L.L. (2006). The Value of Differ- ent Customer Satisfaction and Loyalty Metrics in Predicting Business Performance, Marketing Science, 25 (5). 426-39.. 
Odom, W., Banks, R., Kirk, D, Harper, R., Lindley, S., Sellen, A. (2012). Technology Heirlooms? Considerations for Passing Down and Inheriting Digital Materials. In proceedings of SIGCHI Conference on Human Factors in Computing Systems. Austin, Texas. CHI '12. ACM Press. http://dx.doi.org/10.1145/2207676.2207723

Odom, W., Harper, R., Sellen, A., Kirk, D., Banks, R. (2010). Passing On \& Putting To Rest: Understanding Bereavement in the context of Interactive Technologies. In proceedings of SIGCHI Conference on Human Factors in Computing Systems. Atlanta, USA. CHI '10. ACM Press, 1831-1840. http://dx.doi.org/10.1145/1753326.1753601

Odom, W., Zimmerman, J. \& Forlizzi, J. (2011). Teenagers and their virtual possessions: design opportunities and issues. CHI '11 - Proceedings of the SIGCHI Conference on Human Factors in Computing Systems, 14911500. doi: 10.1145/1978942.1979161

Park, C. W, MacInnis, J.I, Priester, P., Eisengerich, A. and Iacabucci,(2010). Brand Attachment and Brand Attitude Strength: Conceptual and Empirical Differentiation of Two Critical Brand Equity Drivers, Journal of Marketing, 74 (November), 1-17.

Pearce, C. and Artemesia (2009). Communities of Play: Emergent Cultures in Multiplayer Games and Virtual Worlds. Cambridge, MA: MIT Press.

Pine, B. J., and Gilmore, J.H., (1999). The experience economy: Work is theatre and every business a stage. Boston, MA:Harvard Business School Press.

Prahalad, C. K., and Ramaswamy, V.. (2000). Co-opting customer competence. Harvard Business Review, 78 (January-February), 79-87.

Richins M. (1994). Valuing Things, the Public and Private Meanings of Possessions. Journal of Consumer Research, Vol. 21, No. 3 (Dec., 1994), pp. 504-521

Ritzer, G. (2004). The McDonaldization of society. Thousand Oaks, CA: Pine Forge.

Ritzer, G. and Jurgenson, N., (2010). Production, Consumption, Prosumption: The nature of capitalism in the age of the digital 'prosumer'. Journal of Consumer Culture, 10(1), 13-36.

Scarabato, D. Carter-Schneider C. and Kedzior R. (2013) At world's end: Exploring consumer-marketer tensions in the closure of adverworlds, Journal of Marketing Management, 10

Scholz, T., (2013). (ed) Digital Labor: The Internet as Playground and Factory, New York: Routledge.

Sherry, J. F. Jr. (1983) Gift Giving in Anthropological Perspective, Journal of Consumer Research, 10 (2): 157 168.

Sherry, J.F. Jr. (1990). A Sociocultural Analysis of a Midwestern American Flea Market. Journal Of Consumer Research, 17(1), 13-30.

Sheth,J. Sisodia, R. and Sharma, A. (2000), The Antecedents and Consequences of Customer-Centric Marketing, Journal of the Academy of Marketing Science 2000; 28; 55

Slater, D., (1997). Consumer Culture and Modernity. London: Polity.

Spotify, (2013). What is Spotify? Available from: http://www.spotify.com/uk/about-us/press/information/ [Accessed 12 Feb2013].

Slashgear (2013), Steam users eclipse Xbox Live, PSN still far and away tops, October [available at: http://www.slashgear.com/steam-users-eclipse-xbox-live-psn-still-far-and-away-tops-30303588/] 
Slater, D. (2014). Ambiguous goods and nebulous things. Journal of Consumer Behaviour, 13(2). 99-107.

Tapscott, D., and Williams, A.D. , (2006). Wikinomics: How mass collaboration changes everything. New York: Portfolio.

Terranova, T. (2000). Free labor: Producing culture for the digital economy. Social Text, 18(2), 33-58.

Thomson, M., MacInnis, D.J. \& Park, C.W. (2005). The Ties That Bind: Measuring the Strength of Consumers' Emotional Attachments to Brands, Journal of Consumer Psychology, 15 (1). 77-91.

Tinson, J. and Nuttall, P., (2008). Insider Trading? Exploring Familial Intragenerational Borrowing and Sharing. European Advances in Consumer Research, 8, 41-42.

Vargo, S. L., and Lusch, R.F., (2004). Evolving to a new dominant logic for marketing. Journal of Marketing 68 (January), 1-17.

Wallendorf, M. \& Arnould, E. (1988). "My Favorite Things": A Cross-Cultural Inquiry into Object Attachment, Possessiveness, and Social Linkage. Journal of Consumer Research 14: 531-547.

Watkins, R. and Molesworth, M., (2012). Attachment to Digital Virtual Possessions in Videogames. Research in Consumer Behavior, 14, 153-171.

Watkins, R. Molesworth, M. and Denegri-Knott, J. (forthcoming), Ownership and Possession of Digital Virtual Goods, Journal of Marketing Management.

Watson, M. and Shove, E. (2008). Product, competence, project and practice: DIY and the dynamics of craft consumption. Journal of Consumer Culture, 8(1), 69-89.

Wieseke, J., Alavi, S., \& Habel, J. (2014). Willing to Pay More, Eager to Pay Less: The Role of Customer Loyalty in Price Negotiations. Journal of Marketing, 78(6). 17-37. doi:10.1509/jm.13.0104

Zhang J \& Breugelmans E (2012) The Impact of an Item-Based Loyalty Program on Consumer Purchase Behavior. Journal of Marketing Research: February 2012, Vol. 49, No. 1, pp. 50-65.

Zhu, K.X. \& Zhou, Z.Z. (2011), Lock-In Strategy in Software Competition: Open-Source Software vs. Proprietary Software Information Systems Research, Articles in Advance, pp. 1-10,

Zwick, D., Bonsu, S. and Darmody, A., 2008. Putting consumers to work: 'Co-creation' and new marketing govern- mentality. Journal of Consumer Culture, 8(2), 163-196. 